\title{
CYKLICZNE BADANIA JAKOŚCI ŻYCIA NARZĘDZIEM WSPARCIA MIEJSKIEJ STRATEGII ROZWOJU
}

\section{ZAPOMNIJ O PRODUKCIE NARODOWYM BRUTTO, BADAJĄC ROZWÓJ SPOŁECZNY I DOBROSTAN ${ }^{1}$}

\begin{abstract}
Celem systemu gospodarczego jest dostarczanie dóbr i świadczenie usług, jakich potrzebuja ludzie.

Stad tė̇ politycznym problemem ludzkości jest połaczenie trzech rzeczy: efektywności ekonomicznej, sprawiedliwości społecznej i indywidualnej wolności.
\end{abstract}

J. M. Keynes

Przytoczona teza Johna M. Keynesa przypomina, że rozwój ekonomiczny musi opierać się na założeniu, że wymiar społeczny i ekologiczny nie są i nie będą jego hamulcami, natomiast sa i będa jego stymulatorami, poprzez wymuszony tymi wymiarami postęp technologiczny, podnoszenie poziomu wykształcenia społeczeństwa, jego zwiększony udział w podejmowaniu decyzji i w odpowiedzialności za te decyzje, tworzenie nowych miejsc pracy, rozwój aktywności i przedsiębiorczości, wzrost efektywności wykorzystania surowców, materiałów i pracy ludzkiej, a także zwiększenie bezpieczeństwa (rozwój zrównoważony²).

Większość problemów społecznych można odnaleźć w niedorozwoju i/lub nadmiernym rozwoju (nie każdy rozwój jest postępem), procesy makroekonomiczne bowiem, mające wieloletnią perspektywę realizacyjna, w małym stopniu uwzględniają doraźne konsekwencje i dolegliwości, jakie mogą nieść dla konkretnej jednostki, rodziny, zwłaszcza gdy zbyt długie zaniechanie zmian $\mathrm{w}$ tak istotnych dla życia obywateli dziedzinach, jak ochrona zdrowia, za-

1 Teza zaczerpnięta z artykułów: L. Daly i S. McElwee, opublikowanego 3 lutego 2014 r. w „The New Republic" - tytuł: Forget the GDP. Some States Have Found a Better Way to Measure Our Progress oraz A. Schwartz, Forget GDP: The Social Progress Index Measures National Well-Being, http://www.fastcoexist.com/1681830/forget-gdp-the-social-progress-index-measures-nationalwell-being (dostęp: maj 2013).

2 „Rozwój zrównoważony to proces, w ramach którego zaspokajanie bieżących potrzeb społecznych oraz potrzeb przyszłych pokoleń traktowane będzie równoprawnie [...] i łączyć będzie w sposób harmonijny troskę o zachowanie dziedzictwa przyrodniczego i kulturowego narodu z postępem cywilizacyjnym, będącym udziałem wszystkich grup społecznych" (Rezolucja Sejmu RP z 30 marca 1999 roku - Strategia Zrównoważonego Rozwoju Polski do 2025 roku, Warszawa 1999, rozdziały 1-3, s. 13 i n.) 
bezpieczenie na wypadek choroby, starości, niepełnej sprawności, dostęp do kształcenia, bezrobocie itp., może zagrażać efektywności całego układu gospodarczego, a w konsekwencji także politycznego.

Rozwój społeczny (z człowiekiem, a nie dochodem w centrum) ${ }^{3} \mathrm{w}$ odróżnieniu od rozwoju gospodarczego/ekonomicznego oznacza zdolność społeczeństwa do generowania warunków umożliwiających wszystkim członkom osiagnięcie pełnego potencjału, zaspokojenie podstawowych potrzeb oraz służaccych wzmacnianiu/utrzymanie jakości życia jednostek i społeczności. W tym stanie rzeczy wzrost gospodarczy prowadzić musi do zwiększania spójności społecznej (w tym m.in. zmniejszania rozwarstwienia społecznego, wyrównywania szans, przeciwdziałania dyskryminacji, marginalizacji i wykluczeniu) oraz sprzyjać podnoszeniu jakości środowiska naturalnego, m.in. przez ograniczanie szkodliwego wpływu produkcji i konsumpcji na stan i ochronę zasobów przyrodniczych. Inaczej mówiąc, rozwój gospodarczy tworzy materialne warunki do rozwoju społecznego, ten zaś staje się czynnikiem przyspieszającym wzrost gospodarczy. Dla badaczy i decydentów oznacza to wzrost znaczenia tzw. niematerialnych czynników rozwoju ${ }^{4}$ - roli jakościowych i ilościowych parametrów zasobów społecznych ${ }^{5}$ będących w dyspozycji zbiorowości oraz możliwość ich efektywnego wykorzystania.

Stąd też nowym priorytetem polityki społecznej obwołany został dobrostan (well-being), rozumiany jako „zintegrowana metoda funkcjonowania zorientowanego na maksymalizowanie potencjału możliwego do osiagnięcia w środowisku życia jednostki i/lub grupy”6 oraz jako „aktywny proces służący świadomym wyborom w dążeniu do osiagania coraz bardziej satysfakcjonującej egzystencji”'

${ }^{3}$ „To ukierunkowany proces społeczny, w wyniku którego następuje ciagły wzrost pewnych istotnych dla danego społeczeństwa czy społeczności zmiennych. [...] ciag zmian korzystnych dla danej zbiorowości określa się jako postęp społeczny” (P. Sztompka, Socjologia zmian społecznych, Kraków 2005, s. 23 i 24).

${ }^{4}$ Ivan Illich zwraca uwagę na dwoistość znaczenia słowa „rozwój” - łacińskie słowo progressio jest podstawą idei rozwoju, ale może także znaczyć: „szaleństwo, obłąkanie” (www.love-or-money. org/literature/life.htm). Z kolei Sulak Sivaraksa stwierdza, że „[...] w języku pali słowo rozwój (radhana) może znaczyć zarówno postęp, jak i regres [...], a zatem [...] istnieja poważne wątpliwości co do »błogosławieństwa«, jakim ma być rozwój w porównaniu z tak atrakcyjnymi terminami, jak: wolność, demokracja, niezależność, [...] kolejne fazy rozwoju przebiegają bowiem w taki sposób, że bogaci stają się jeszcze bogatsi, biedniejsi zaś dalej ubożeją - ale bogatsi nie są wcale szczęśliwsi (S. Sivaraksa, Seeds of Peace: Development as It People Mattered, Parallax Press, Berkeley 1992, s. 15 i n.).

${ }^{5}$ Zasoby społeczności to wszystko co służy osiaganiu celów, rozwiązywaniu problemów, eliminowaniu zagrożeń oraz co umożliwia ludziom realizację zadań życiowych, aspiracji lub wartości. Moga być zarówno bardzo namacalnymi w swej istocie - pieniądze, mieszkanie, żywność, opieka domowa i instytucjonalna, transport, odzież, jak i walorami niematerialnymi - wiedza, odwaga, pomysłowość, inicjatywa, zachęta, humanizm, miłość itp. Obejmuja one zarówno konkretne jednostki z ich osobościowymi i materialnymi walorami oraz ich najbliższe społeczne otoczenie (rodzina, przyjaciele, znajomi, sasiedzi), jak i formalne (władze publiczne, instytucje) i nieformalne grupy (organizacje, stowarzyszenia).

${ }^{6}$ To jedna z najwcześniejszych definicji: zob. H. Dunn, High Level Wellness, Arlington 1961, s. 84.

${ }^{7}$ B. Hettler, Wellness Promotion and Risk Reduction on University Campus, w: M. Faber, A. Reinhardt (red.), Promotion Health through Risk Reduction, Collier Macmillan Publishers, London 1982, s. 207 i n. 
Pojawiła się także w ostatnich latach nowa dziedzina analiz i oceny dobrostanu psychospołecznego na poziomie jednostek i szerszych zbiorowości - to ekonomika szczęścia łącząca techniki analizy i wskaźniki używane przez ekonomistów z tymi, które są istotą warsztatu psychologów8

$\mathrm{W}$ ten sposób do tradycyjnych obszarów polityki społecznej (zdrowie, bezpieczeństwo socjalne, pomoc społeczna), doszły m.in. takie kwestie, jak mieszkalnictwo i zatrudnienie wraz z przypisanymi im świadczeniami, edukacja i rynek pracy, a także komunikowanie, podróżowanie, kupowanie oraz zajęcia czasu wolnego. Celem władz publicznych jest zatem nie tylko dbałość o to, by jednostki i rodziny (zwłaszcza żyjące w trudnych warunkach) miały dostęp do systemu wsparcia społecznego i zasobów społecznych umożliwiających osiagnięcie potencjału koniecznego do samodzielnego funkcjonowania, lecz także by osiagały one poprawę funkcjonowania w obszarach decydujących o jakości życia, w tym zwłaszcza dających poczucie bezpieczeństwa socjalnego i zdrowotnego.

$\mathrm{W}$ tej sytuacji konieczne jest poszerzanie wachlarza narzędzi pomiaru dobrostanu społecznego poza standardowy, tradycyjnie stosowany w analizach makroekonomicznych wskaźnik produktu krajowego brutto $(\mathrm{PKB})^{9}-$ nie jest to wyłącznie przejaw woli politycznej, to dzisiaj sfera ko niecz ności.

W wielu krajach od wielu lat stosowane są rozbudowane, alternatywne wobec PKB wskaźniki rozwoju (czasami grupowane w syntetyczne indeksy), takie jak np. ${ }^{10}$ :

1. Gross Environmental Sustainable Development Index (GESDI) - mierzy jakość wzrostu i rozwoju za pomocą 200 indykatorów wartości i dóbr nierynkowych (innych niż pieniądze) ułożonych w czterech kategoriach: ludzie, dostępne zasoby, środowisko i rozwój gospodarczy.

2. Gross Sustainable Development Product (GSDP) ${ }^{11}$ - to miara całkowitej wartości produkcji w regionie w określonym czasie. Mierzy koszty wzrostu i rozwoju, uwzględniając ceny rynkowe transakcji dóbr oraz usług w gospodarce. Indeks określany jako przewidywany wskaźnik, który ma zastapić dotychczasowy PKB.

3. Fordham Index of Social Health (FISH) - uwzględnia 16 wskaźników socjoekonomicznych: śmiertelność niemowląt, nadużycia i ubóstwo dzieci, sa-

${ }^{8}$ Zob. C. Graham, The Economics of Happiness. Insights on Globalization from a Novel Approach, „World Economics” 6, 2005, nr 3, s. 41-55; J. Czapiński, Ekonomia szczesścia i psychologia bogactwa, „Nauka” 2012, nr 1, s. 51-88; K. Włodarczyk, Ekonomia wobec poczucia szczęścia, „Ruch Prawniczy, Ekonomiczny i Socjologiczny” 76, 2014, z. 4, s. 347-363.

${ }_{9}^{9} \mathrm{PKB}$ opisuje zagregowaną wartość dóbr i usług finalnych wytworzonych na terenie danego kraju w określonej jednostce czasu (najczęściej w ciąu roku). Pomiary PKB per capita dokonywane przez kilka międzynarodowych instytucji lokują nasz kraj na zróżnicowanych miejscach w tym rankingu - według danych Międzynarodowego Funduszu Walutowego w 2013 r. zajmowaliśmy 49 miejsce na 187 krajów poddanych badaniu; 46 miejsce wśród 182 państw analizowanych przez Bank Światowy i 52 miejsce na 195 krajów według rankingu CIA.

${ }_{10}$ J. van den Bergh, M. Antal, Evaluating Alternatives to GDP as Measures of Social Welfare/Progress, Work Package 2002, MS211, „Research paper on evaluating alternatives to GDP as measures of Social Welfare and Progress", Working Paper no. 56, 2014. www.foreurope.eu/.../ WWWforEurope_WPS_no056 (dostęp: maj 2014).

${ }^{11}$ Indeks stosowany przez Global Community Assessment Centre and the Society for World Sustainable Development. 
mobójstwa młodzieży, uzależnienia ludzi młodych, spadek liczby studiujacych, średnia płaca, bezrobocie, ubezpieczenia zdrowotne, ubóstwo wśród seniorów, ubezpieczenia zdrowotne dla ludzi starych, zgony na drogach spowodowane przez pijanych kierowców, morderstwa, dystrybucja kartek żywnościowych, mieszkanie, nierówności dochodowe.

4. Genuine Progress Indicator (GPI) - 18 wskaźników: niepłatna praca (prowadzenie gospodarstwa domowego, opieka nad chorymi, dziećmi, przestępczość, rozpad rodziny, praca w gospodarstwie domowym, praca wolontariacka, dystrybucja dochodu, wyczerpanie zasobów, skażenia, wydatki na obronę, szkody (powodzie, dziura ozonowa itp.), zmiany w wypełnianiu czasu wolnego, wiek dóbr trwałego użytku i infrastruktury społecznej, aktywa zagraniczne, usługi (drogi, ulice), utrata czasu wolnego, koszty wypadków drogowych, koszty niepełnego zatrudnienia, koszty hałasu i skażeń w gospodarstwie domowym.

5. Human Development Index (HDI) - syntetyczny miernik zbudowany w $1990 \mathrm{r}$. i stosowany przez UNDP agendę ONZ. Indeks opisuje efekty w zakresie społeczno-ekonomicznego rozwoju poszczególnych. Ocenia kraje na trzech płaszczyznach: „długie i zdrowe życie” (long and healthy life), „wiedza” (knowledge) i „dostatni standard życia” (decent standard of living) ${ }^{12}$.

6. Physical Quality of Life Index (PQLI) - wartość wskaźnika jest średnia z trzech statystyk: poziomu alfabetyzacji, śmiertelności niemowląt i średniej trwania życia (wszystkie odkładane na skali od 0 do 100).

7. Social Progress Index (SPI) - obejmuje trzy grupy wskaźników:

a) potrzeby podstawowe człowieka (żywienie i podstawowa opieka zdrowotna, woda i higiena, schronienie, bezpieczeństwo osobiste);

b) możliwości (prawa jednostki, wolność osobista i wybór, tolerancja i inkluzja, dostęp do wyższego poziomu edukacji);

c) fundamenty dobrostanu (dostęp do wiedzy podstawowej, dostęp do informacji i komunikacji, zdrowie i dobrostan psychospołeczny, zrównoważony ekosystem $)^{13}$;

8. Happy Planet Index (HPI) - jedna z pierwszych globalnych miar zrównoważonego dobrostanu, wykorzystująca globalne dane dotyczące doświadczane samopoczucie, długość życia, a także tzw. ślad ekologiczny. Happy Planet Index to iloczyn doświadczanego dobrostanu psychospołecznego i przewidywanej długości życia dzielony przez wartość tzw. śladu ekologicznego (Ecological Footprint), oznaczającego szacowaną ilość hektarów powierzchni lądu i morza potrzebną do rekompensowania zasobów zużytych w procesie konsumpcji i absorpcji odpadów ${ }^{14}$. To analiza zapotrzebowania człowieka na zasoby naturalne

${ }^{12}$ Polska w 2012 r. lokowała się na 39 miejscu wśród 207 państw objętych badaniem.

${ }_{13}$ M. E. Porter, S. Stern, M. Green, Social Progress Index 2014, Washington 2014. W badaniu z 2014 r. Polska znalazła się na 27 miejscu wśród 132 krajów objętych pomiarem (www.socialprogressimperative.org/data/sp; dostęp: maj 2014).

${ }^{14}$ Zob.: R. Easterlin, Explaining Happiness, „Proceedings of the National Academy of Sciences" 100, 2003, nr 19; C. Graham, The Economics of Happiness. Insights on Globalization from a Novel Approach, „World Economics” 6, 2005, nr 3, s. 41-55; R. Layard, Happiness: Lessons from a New Science, Penguin Press, New York 2005; R. Layard, Happiness and Public Policy: A Challenge the Profession, „The Economic Journal” 116, 2006, C24-C33; M. Anielski, The Economics of 
biosfery, prowadzącego długie, szczęśliwe życie, przy jednoczesnym zachowaniu warunków dla przyszłych pokoleń, aby mogły zrobić to samo. Indeks stanowić ma podstawowe narzędzie umożliwiające decydentom uwzględnianie fundamentalnych kwestii społecznych i ekologicznych w toku podejmowania kluczowych decyzji ${ }^{15}$.

O przydatności nowych, alternatywnych wobec PKB miar rozwoju społeczno-ekonomicznego świadczą wyniki wieloletnich badań porównawczych prowadzonych w USA i Kanadzie, z których wynika, że ze wzrostem PKB dobrostan jednostek nie musi rosnać $\mathrm{w}$ takim samym stopniu i zakresie ${ }^{16}$ :

1) w USA Fordham Index of Social Health (FISH) spadał od 1973 r., gdy w tym samym czasie PKB wzrastał, w Kanadzie zaś indeks FISH pozostaje na poziomie z 1985 r., mimo że PKB w tym czasie wzrastał.

2) w USA jakość życia pogarszała się od 1970 r. w coraz szybszym tempie spadał Genuine Progress Indicator (GPI), rosła zaś wartość PKB. W Kanadzie, gdy PKB wzrastał, indeks GPI nie tylko nie wzrósł, ale pozostał na tym stałym poziomie ${ }^{17}$.

Miary socjokulturowe dobrostanu społecznego, ta swoista społeczn a rachunkow ość, stała się znaczącym narzędziem planowania społecznego służącego poprawie jakości życia. Barierą w upowszechnianiu nowych, bardziej efektywnych narzędzi analizy i porównań rozwoju społeczno-gospodarczego jest nadal utrzymujacy się sceptycyzm lokalnych decydentów wobec stosowania i adaptowania wskaźników społecznych w praktyce planowania i podejmowania decyzji, a także niski poziom danych dostarczanych przez oficjalna statystykę oraz przyjęte niewłaściwe wskaźniki potrzeb.

Rolą państwa i jego agend (rządowych, samorządowych) powinno być w tej sytuacji tworzenie warunków i możliwości działania oraz wspieranie aktywności indywidualnej i zbiorowej. W takim ujęciu człowiek z jego prawem udziału w decyzjach oraz zdrowego i produktywnego rozwoju jest aktywnym podmiotem procesów społecznych i ekonomicznych. W sferze działań socjalnych celem głównym jest dbałość o to, by jednostki i rodziny miały dostęp do zasobów społecznych umożliwiających osiagnięcie potencjału ko-

Happiness Book. The Concept of Genuine Wealth and "The Economics of Happiness, New Society Publishers, Gabriola Island 2007; H. Johns, P. Ormerod, Happiness, Economics and Public Policy, The Institute of Economic Affairs, Profile Books Ltd, London 2007; M. Murphy (red.), Happy Planet Index: Report 2012. A Global Index of Sustainable Well-being, London 2012.

${ }^{15}$ W 2011 r. zajmowaliśmy w tym rankingu 68 miejsce wśród 151 krajów poddanych badaniu (20 pozycja wśród państw UE). Zob. M. Murphy (red.), Happy Planet Index: Report 2012. A Global Index of Sustainable Well-Being, London 2012.

${ }^{16}$ Prawidłowość ta nosi nazwę paradoksu Easterlina polegającego na tym, że o ile jednostki/społeczeństwa zamożniejsze są szczęśliwsze, o tyle wzrost dochodów ludzi i społeczeństw nie zwiększa wcale ich poczucia szczęścia (dobrostanu). Paradoks ten wyjaśnia się zjawiskiem tzw. hedonistycznej bieżni: aspiracje zwiększają się wraz ze wzrostem dochodów, jak i wówczas, gdy podstawowe potrzeby sa zaspokojone. Zob. R. Easterlin, Does Economic Growth Improve the Human Lot? Some Empirical Evidence, w: P. David, M. Reder, Nations and Households in Economic Growth: Essays in Honour of Moses Abramovitz, Academic Press, Inc., New York 1974.

${ }_{17}$ Alternatives to the GDP, www.consultmcgregor.com/.../GDP_and_GPI.pdf (dostęp: listopad 2012). Podobne zależności obserwujemy dla danych relacjonujących PKB i alternatywnymi pomiarami dobrostanu społecznego. 
niecznego do samodzielnego funkcjonowania oraz systemu wsparcia społecznego, uruchamianego wtedy, gdy zajdzie taka potrzeba (np. ubóstwo, choroba, niepełnosprawność, kataklizmy itp.). Przyjmuje się jednak, że prawo do bezpieczeństwa socjalnego nie może być realizowane wyłącznie poprzez system zasiłków, zapomóg i subwencji, nie generuje on bowiem aktywności jednostkowej i zbiorowej.

Wielu ekspertów uważa jednak, że mimo wielu nowych narzędzi pomiaru, nadal zbyt wiele uwagi poświęca się PKB przy orzekaniu i ocenianiu poziomu i jakości rozwoju społeczeństw. Zdaniem Frances Stewart: „wzrost PKB nie uwzględnia tego, jak dochód jest dystrybuowany pomiędzy różne grupy ludności, nie uwzględnia dóbr publicznych, zatrudnienia - czyli tego wszystkiego, co ma fundamentalne znaczenie dla poprawy jakości życia" 18 .

\section{JAKOŚĆ ŻYCIA - KWESTIE DEFINICYJNE}

Po raz pierwszy terminu ,jakość życia” użył Artur Pigou w 1920 r. w książce o ekonomii, dobrobycie i pomocy społecznej, gdy poruszał problemy wsparcia rządowego dla klas niższych i jego wpływu na ich poziom życia oraz na finanse państwowe. Istnieje blisko 100 różnych definicji jakości życia - pojęcie stosowane wymiennie z terminem „szczęście” lub „dobre życie”, czasem stosowane w znaczeniu „subiektywnego dobrostanu” lub „satysfakcji życiowej" 19 .

Największe zainteresowanie badaniami i teorią jakości życia odnotowujemy w krajach bardzo bogatych, co zdaniem kanadyjskiego filozofa Storrsa McCalla „określić można jako nostalgię za czymś, co zostało utracone - jest pośrednim przyznaniem się do tego, że współczesne społeczeństwo postindustrialne, mimo coraz większego dostatku, poszerzenia komunikacji i czasu wolnego nie uczyniło zbytniego postępu w poprawie ogólnej kondycji swych członków”" Prawdopodobnie z tychże względów „jakość życia” weszła prawie natychmiast do sfery globalnej polityki - ONZ, OECD i UE uczyniły ją politycznym priorytetem.

Dawniej zwana „satysfakcją życiowa” lub „subiektywnym dobrym samopoczuciem/dobrostanem”, dzisiaj określana jako „globalna jakość życia”. To jest najszersze ujęcie obejmujące wpływy na wszystkie wymiary życia, które maja wkład w bogactwo i nagrodę jednostki, przyjemność i ból - te wymiary obejmują, ale nie ograniczają się - do zdrowia.

18 F. Stewart, Human Development as an Alternative Development Paradigm, prezentacja, s. 6, http://hdr.undp.org/en/media/Stewart.pdf (dostęp: wrzesień 2010).

19 Wieloznaczność pojęcia oraz związane z tym trudności definicyjne skłaniają niektórych badaczy do skrajnego stanowiska postulującego usunięcie terminu ,jakość życia” ze słownika naukowego (Quality of Life. Resource, http://www.atsqol.org/key.asp; dostęp: maj 2004).

${ }^{20}$ Quality of Life - Underlying Philosophy, http://www.globalideasbank.org/BOV/BV-376. HTML (dostęp: maj 2004). 
W natłoku definicji i narzekań badaczy na trudności w określeniu, czym jest jakość życia, brakuje podejścia analitycznego, syntetyzującego najważniejsze elementy definicyjne, które nie budzą kontrowersji i dają się efektywnie operacjonalizować. Pozostając w zgodzie z wcześniej wygłoszoną teza, autor niniejszego opracowania przyją rozumienie jakości życia jako os obistego bilansu pozytywnych i negatywnych cech, statusów, sytuacji, stanów oraz zdarzeń charakteryzujących życie konkretnej osoby, obejmujacego jej doświadczenia w sferze biologicznej, psychologicznej, interpersonalnej, społecznej i ekonomicznej. To wielowymiarowy zestaw wartości, jedyny w swoim rodzaju dla każdej osoby i kontekstu, w jakim ona funkcjonuje. Jakość życia określa zatem stopień, w jakim jednostka osiaga cele życiowe i/lub doświadcza/doznaje przyjemności z realizacji znaczacych dla niej możliwości - dlatego też oglądana jest przez pryzmat ocen i spostrzeżeń tych, co tego wszystkiego doświadczaja.

Wśród wielu domen jakości życia miejsce szczególne - jeśli nie priorytetowe dla jednostki - zajmuje zdrowie, jako wydzielony obszar będący zbiorem osobistych doświadczeń, przekonań, wiedzy i oczekiwań związanych z postrzeganiem zdolności do funkcjonowania i zadowolenia z życia (role, funkcje i zadania), determinowanych fizycznym, psychologicznym i społecznym wymiarem zdrowia.

Jakość życia w wymiarze indywidualnym przekłada się na subiektywnie postrzeganą przez jednostkę pozycję i status życiowy na tle kontekstu kulturowego i systemu wartości będącego jej udziałem oraz w powiązaniu z osobistymi celami, oczekiwaniami, standardami i związkami.

Bieguny definicyjne jakości życia (tab. 1) rozciagają się od mało precyzyjnego określenia przyjmującego, że termin ten „konsumuje” wszystko to, co oznacza zdolność do prowadzenia normalnego życia i samourzeczywistnienia, do bardziej pogłębionego podejścia obejmującego:

1) sens życia i przypisywaną mu rangę - traci na znaczeniu pytanie, kim jestem, na rzecz tego, co i jak czuję oraz sądzę o sobie. Zatem tyle definicji jakości życia, ile osób o to zapytamy, i dlatego termin ten powinien być oglądany oczyma tych, co go doświadczaja;

2) szczęście lub satysfakcję - definiowanie jakości życia odbywa się nie tyle w kategoriach ogólnego lub przeciętnego szczęścia, lecz utrzymywania się niezbędnych dla jego osiagania warunków w konkretnym regionie świata, w określonej kulturze;

3) osiąganie celów osobistych - jakość życia rozumiana jako wypadkowa zestawu podstawowych wartości przetłumaczonych w mniejszym lub większym stopniu na cele i oczekiwania jednostki; to stopień, w jakim jednostka osiaga cele życiowe;

4) zakres, do którego jednostka jest zdolna osiągnać poczucie bezpieczeństwa, własnej wartości oraz możliwość wykorzystania zdolności intelektualnych, psychofizycznych i czysto fizycznych w dążeniu do celów osobistych; 
5) indywidualne znaczenie dobrego samopoczucia (lub braku zadowolenia) mającego swe źródło w tych obszarach (domenach) życia, które jednostka uznaje za znaczące, ważne - to stopień, w jakim jednostka doświadcza/doznaje przyjemności z realizacji znaczących dla niej możliwości;

6) odzwierciedlenie poziomu zaspokojenia potrzeb i zadowolenia uzyskiwanego we własnym środowisku społecznym - to poziom koniecznej satysfakcji w obrębie potrzeb fizjologicznych, psychologicznych i społecznych oraz w sferze materialnej, strukturalnej, a także w obszarze aktywności. Przeważa pogląd, że ludzkie potrzeby stanowią fundament jakości życia, tę zaś tworzy poziom zadowolenia z ich zaspokojenia;

7) społeczną użyteczność i preferencje/priorytety - wykorzystanie ocen i danych odzwierciedlajacych preferencje/priorytety jednostek dla określonych domen i uwzględnianie poprawy współczynników w połączeniu z pojedynczymi miarami, dostosowującymi jakość życia do osiaganych standardów egzystencji).

\section{Tabela 1}

Główne konteksty definicyjne jakości życia

\begin{tabular}{|c|c|}
\hline Autor & Jakość życia \\
\hline $\begin{array}{l}\text { Storrs McCall } \\
\text { (Department of Philoso- } \\
\text { phy at Canada's McGill } \\
\text { University, 1975) }\end{array}$ & $\begin{array}{l}\text { Pomiar zasięgu, do którego ludzka potrzeba szczęścia jest real- } \\
\text { izowana - np. oczekiwania/żądania/potrzeby, które są koniecznym, } \\
\text { niezbędnym (chociaż niewystarczającym) warunkiem czyjegoś } \\
\text { szczęścia, bez których przedstawiciel rasy ludzkiej nie może być } \\
\text { szczęśliwy. Jakość życia współokreślają warunki niezbędne do } \\
\text { osiagania szczęścia w konkretnym regionie świata, w okré́lonej } \\
\text { kulturze }\end{array}$ \\
\hline C. L. Engquist (1975) & $\begin{array}{l}\text { Zakres, do którego jednostka jest zdolna osiagnąć poczucie bezpie- } \\
\text { czeństwa i własnej wartości oraz ma możliwość wykorzystania zdol- } \\
\text { ności intelektualnych, psychofizycznych i czysto fizycznych w dąże- } \\
\text { niu do celów osobistych }\end{array}$ \\
\hline $\begin{array}{l}\text { A. Campbell (1976) } \\
\text { J. Flanagan }(1978,1980) \\
\text { T. Tomaszewski }(1984)\end{array}$ & $\begin{array}{l}\text { Ustalana na podstawie zbioru pewnych, odgórnie przyjętych i jed- } \\
\text { nakowych dla wszystkich, kryteriów - aspektów życia (bogactwo } \\
\text { przeżyć, poziom świadomości, poziom aktywności, twórczość, współ- } \\
\text { uczestnictwo w życiu społecznym). Określone z góry sfery życia } \\
\text { (małżeństwo, życie rodzinne, zdrowie, sąsiedzi, znajomi, zajęcia do- } \\
\text { mowe, praca zawodowa, życie w danym kraju, miejsce zamieszka- } \\
\text { nia, czas wolny, warunki mieszkaniowe, wykształcenie i standard } \\
\text { życia) mogą mieć różne znaczenie dla badanej osoby - jeśli któraś } \\
\text { z nich jest mało istotna, jej niska ocena nie będzie mieć wpływu na } \\
\text { jakość życia, natomiast im większe jest ich spełnienie, tym wyższa } \\
\text { jest jakość życia }\end{array}$ \\
\hline J. Hörnquist (1989) & $\begin{array}{l}\text { Oznacza poziom koniecznej satysfakcji w obrębie potrzeb fizjolo- } \\
\text { gicznych, psychologicznych i społecznych oraz w sferze materialnej, } \\
\text { strukturalnej, a także w obszarze indywidualnej aktywności }\end{array}$ \\
\hline M. Oleson (1990) & $\begin{array}{l}\text { Jest jednostkowym szczęściem i/lub zadowoleniem z tych dziedzin } \\
\text { życia, które indywiduum traktuje jako dla niego ważne, znaczące }\end{array}$ \\
\hline
\end{tabular}




\begin{tabular}{|l|l|}
\hline \multicolumn{1}{|c|}{ Autor } & \multicolumn{1}{c|}{ Jakość życia } \\
\hline $\begin{array}{l}\text { D. Revicki i R. Kaplan } \\
\text { (1992) }\end{array}$ & $\begin{array}{l}\text { Wykorzystanie ocen i danych odzwierciedlających preferencje/prio- } \\
\text { rytety dla stanu zdrowia i uwzględnianie poprawy współczynników } \\
\text { chorobowości i umieralności w połączeniu z pojedynczymi miarami, } \\
\text { dostosowującymi jakość do lat życia }\end{array}$ \\
\hline H. Sęk (1993) & $\begin{array}{l}\text { Rozpatrywana w wymiarze subiektywnym pochodzi od wewnętrz- } \\
\text { nych procesów wartościowania różnych sfer życia i życia jako cało- } \\
\text { ści. Zależy od struktury potrzeb, indywidualnego systemu wartości } \\
\text { oraz indywidualnego pojęcia sensu życia }\end{array}$ \\
\hline $\begin{array}{l}\text { Światowa Organizacja } \\
\text { Zdrowia (1993) }\end{array}$ & $\begin{array}{l}\text { Postrzegana przez jednostkę pozycja i status życiowy na tle kon- } \\
\text { tekstu kulturowego i systemu wartości będących jej udziałem, } \\
\text { w powiazaniu z osobistymi celami, oczekiwaniami, standardami } \\
\text { i związkami }\end{array}$ \\
\hline $\begin{array}{l}\text { K. de Walden-Gałuszko } \\
\text { (1994) }\end{array}$ & $\begin{array}{l}\text { Ocena własnej sytuacji życiowej, dokonana w określonym czasie } \\
\text { i uwzględniająca przyjętą hierarchię wartości lub też różnica po- } \\
\text { między realną sytuacją człowieka a sytuacją przez niego wymarzo- } \\
\text { ną }\end{array}$ \\
\hline OECD (1997) & $\begin{array}{l}\text { Poziom dobrostanu mierzony za pomoca wskaźników społecznych, } \\
\text { nie zaś przez wskaźniki ilościowe dochodu i produkcji }\end{array}$ \\
\hline $\begin{array}{l}\text { Władze miasta Singapuru } \\
(2000)\end{array}$ & $\begin{array}{l}\text { Poziom dobrostanu, satysfakcji i standardu życia - stopień, w jakim } \\
\text { jednostka doświadcza/doznaje przyjemności w znaczących dla niej } \\
\text { sferach }\end{array}$ \\
\hline R. Cichocki (2005) & $\begin{array}{l}\text { Wyznaczana przez zewnętrzne warunki w otoczeniu jednostki } \\
\text { oraz przez subiektywną ocenę tych warunków, które uznaje ona } \\
\text { za istotne }\end{array}$ \\
\hline
\end{tabular}

Źródło: opracowano na podstawie: Quality of Life - Underlying Philosophy, http://www.globalideasbank. org/bov/bv-376.html; C. L. Engquist, J. E. Davis, R. H. Bryce, Can Quality of Life Be Evaluated?, „Hospitals" 53, 1979, s. 97-100; J. C. Flanagan, Measurment of Quality of Life: Current State of the Art, „Archives of Physical Medicine and Rehabilitation” 63, 1982, s. 56-59; M. Oleson, Subiectively Perceived Quality of Life, „Image” 1990, s. 187-190; J. Hörnquist, Quality of Life: Concept and Assessment, „Scandinavian Journal of Public Health" 18, 1990, nr 1, s. 69-79; D. A Revicki, R. M. Kaplan, Relationship between Psychometric and Utility-based Approaches to the Measurement of Health-related Quality of Life, "Quality of Life Research" 2, 1992, s. 477-487; World Health Organization, Study Protocol for the World Health Organization Project to Develop a Quality of Life Assessment Instrument (WHOQOL), „Quality of Life Research" 1993, nr 2, s. 153-159; Glossary of Environment Statistics, Studies in Methods, Series F, No. 67, United Nations, New York 1997; H. Sęk, T. Pasikowski, Jakość zyycia i zdrowia a sens koherencji w kontekście spotecznym, w: L. Wołowicka (red.), Jakość życia w naukach medycznych, Poznań 2001, s. 17-29; A. Brzezińska, M. Stolarska, J. Zielińska, Poczucie jakości życia w okresie dorostości, w: K. Appelt, J. Wojciechowska (red.), Zadania i role spoteczne w okresie dorostości, Poznań 2001, s. 103-115; R. Cichocki (red.), Wskaźniki jakości życia mieszkańców Poznania, Poznań 2005, s. 27; A. Aleksińska, Pojęcie jakości życia, Psychologia net.pl (dostęp: grudzień 2013).

Sumując tę część rozważań, należy stwierdzić, że jakość życia sensu stricto to zjawisko subiektywne, jest bowiem „rezultatem wewnętrznych procesów wartościowania różnych sfer życia i życia jako całości. To wartościowanie zależy od struktury potrzeb i indywidualnego systemu wartości, a w szczególności od indywidualnego pojęcia sensu życia" ${ }^{21}$.

${ }^{21}$ H. Sęk, Jakość życia a zdrowie, „Ruch Prawniczy, Ekonomiczny i Socjologiczny” 1993, z. 2, s. 103 i n. 
Subiektywna samoocena cech i właściwości jednostki, zróżnicowanych środowiskowo i zmieniajacych się pod wpływem konkretnych warunków i położenia, dotyczy cech, które decydują o zdolności zaspokojenia potrzeb, realizacji celów osobistych i funkcjonowania człowieka w czterech poziomach aktywności: fizycznym, materialnym, społecznym i emocjonalno-intelektualnym. Te subiektywne aspekty jakości życia pozostaja pod wpływem ,zespołu warunków życia człowieka, atrybutów świata przyrody (również struktury organizmu człowieka warunkujacych poziom funkcjonowania układów biologicznych), przedmiotów i kultury oraz atrybutów człowieka związanych z poziomem życia i pozycją społeczną"22.

Tak więc nie w pełni uzasadnione i logiczne zarazem jest proste dzielenie jakości życia na obiektywną i subiektywna - coraz większą aprobatę zyskuje wyrażany od kilkunastu lat przez autora niniejszego artykułu pogląd, by traktować tzw. obiektywny wymiar jakości życia jako zbliżony znaczeniowo do pojęcia warunków życia (lub poziomu życia), które oznaczają całokształt obiektywnych warunków o charakterze infrastrukturalnym (diagram 1), w jakich żyje społeczeństwo (grupy społeczne, gospodarstwa domowe i jednostki).

Diagram 1

Socjoekonomiczny i środowiskowy kontekst jakości życia

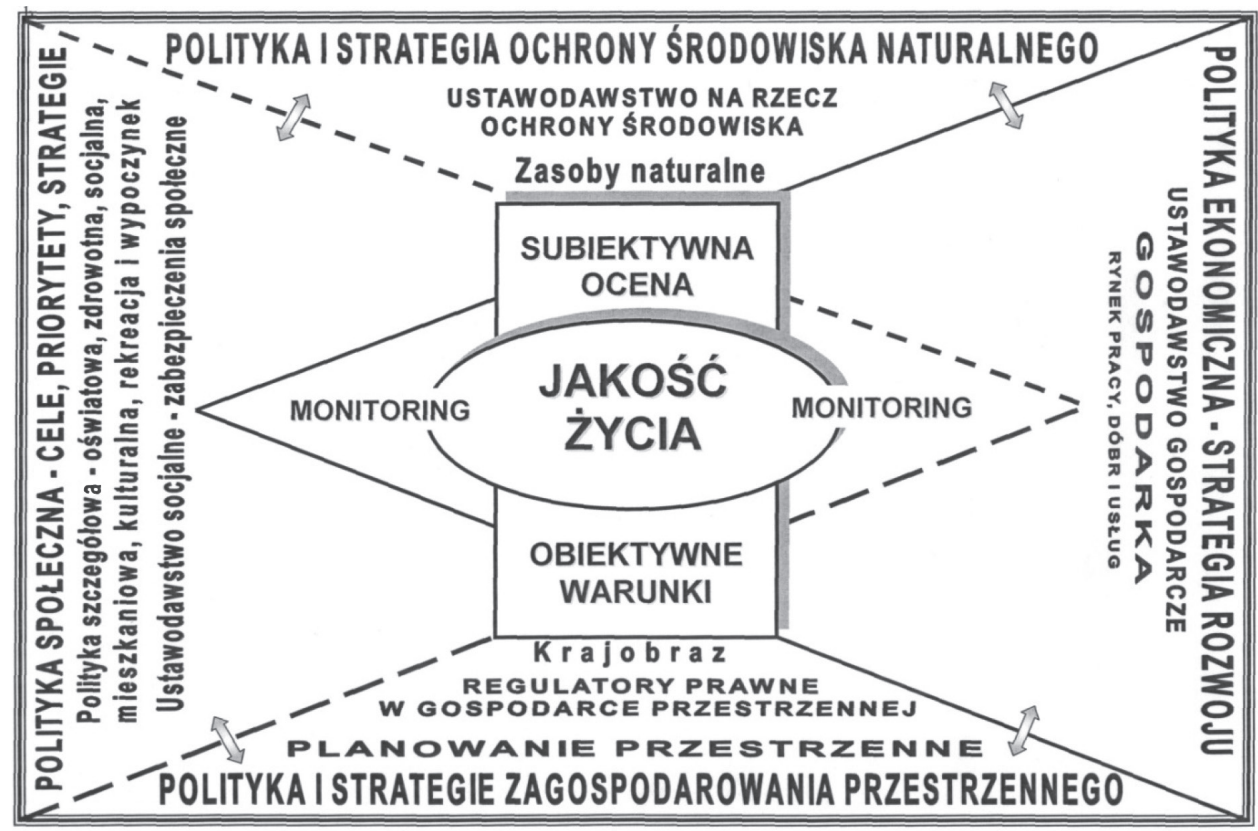

Źródło: opracowanie własne.

${ }^{22}$ H. Sęk nazywa te uwarunkowania „wymiarem obiektywnym jakości życia” - ibidem. 
Liczne taksonomie dziedzin ważnych dla jakości życia proponowane przez badaczy z zakresu socjologii, psychologii, gerontologii i nauk medycznych oparte były na badaniach populacyjnych wśród zróżnicowanych kategorii społecznych. Jedną z pierwszych i najbardziej znaną jest taksonomia Flanagana, który zaproponował 15 wymiarów jakości życia zblokowanych w 5 dziedzinach ${ }^{23}$, które w latach późniejszych inni badacze rozbudowywali w zależności od przyjętych celów badawczych:

1) fizyczny i materialny dobrostan (dobrostan materialny i bezpieczeństwo finansowe, zdrowie i bezpieczeństwo osobiste),

2) stosunki z innymi ludźmi (stosunki ze współmałżonkiem/partnerem, posiadanie i wychowywanie dzieci, stosunki z rodzicami, krewnymi, stosunki z przyjaciółmi),

3) aktywność społeczna, obywatelska i na poziomie społeczności (pomaganie i wspieranie innych, partycypacja w sprawach lokalnych i ponadlokalnych),

4) rozwój osobisty, spełnienie się (rozwój intelektualny, rozumienie i planowanie, kariera zawodowa, kreatywność i ekspresja osobista),

5) rekreacja (socjalizacja, pasywne i naśladowcze formy aktywności rekreacyjnej, uczestnictwo w aktywnych formach rekreacji).

Osobista ocena zadowolenia z życia wikła ze sobą dwa rodzaje subiektywnych okoliczności:

1) znaczenie, jakie dla jednostki ma określona dziedzina życia, oraz

2) jakie otrzymuje ona zadowolenie na tej właśnie płaszczyźnie.

Tak więc im mniejsza ranga konkretnej dziedziny życia dla jednostki, tym słabszy wpływ na ogólną ocenę jakości życia. Niezadowolenie z określonej płaszczyzny życia, do której jednostka przywiązuje dużą wagę powinna w oczywisty sposób wpływać na niższy poziom zadowolenia z życia w ogóle - całkowita jakość życia nie zależy od każdej z domen z osobna, ale od nich wszystkich razem (schemat 1 ).

Dotychczasowe rezultaty badań polskich i międzynarodowych pozwoliły ustalić, że:

1) stosunki interpersonalne okazują się najwyżej ocenioną przez ludzi domeną jakości życia;

2) rozwój osobisty to z kolei dziedzina jakości życia, która z czasem zyskuje najwięcej na poszczególnych skalach;

3) godność i poczucie własnej wartości wykazuja znaczący, acz stabilny wzrost oceny w czasie;

4) znaczącym czynnikiem obniżającym jakość życia były trudności w dostępie do infrastruktury i usług społecznych ${ }^{24}$.

${ }^{23}$ J. C. Flanagan, A Research Approach to Improving our Quality of Life, „American Psychology" 33, 1978, s. 138-147.

${ }^{24}$ Indeks Jakości Życia - oblicza się punkty dla całości skali i dla czterech podskal: 1 - punktacja całkowita Indeksu Jakości Życia, 2 - punktacja dla podskali zdrowie i funkcjonowanie, 3 - podskali socjoekonomicznej, 4 - podskali psychologicznej/duchowej. Polska w 2014 r. znalazła się na 33 pozycji wśród 86 krajów poddanych badaniu. J. Czapiński, T. Panek (red.), Diagnoza Społeczna 2013. Warunki i jakość życia Polaków, Warszaw 2013. 
Schemat 1

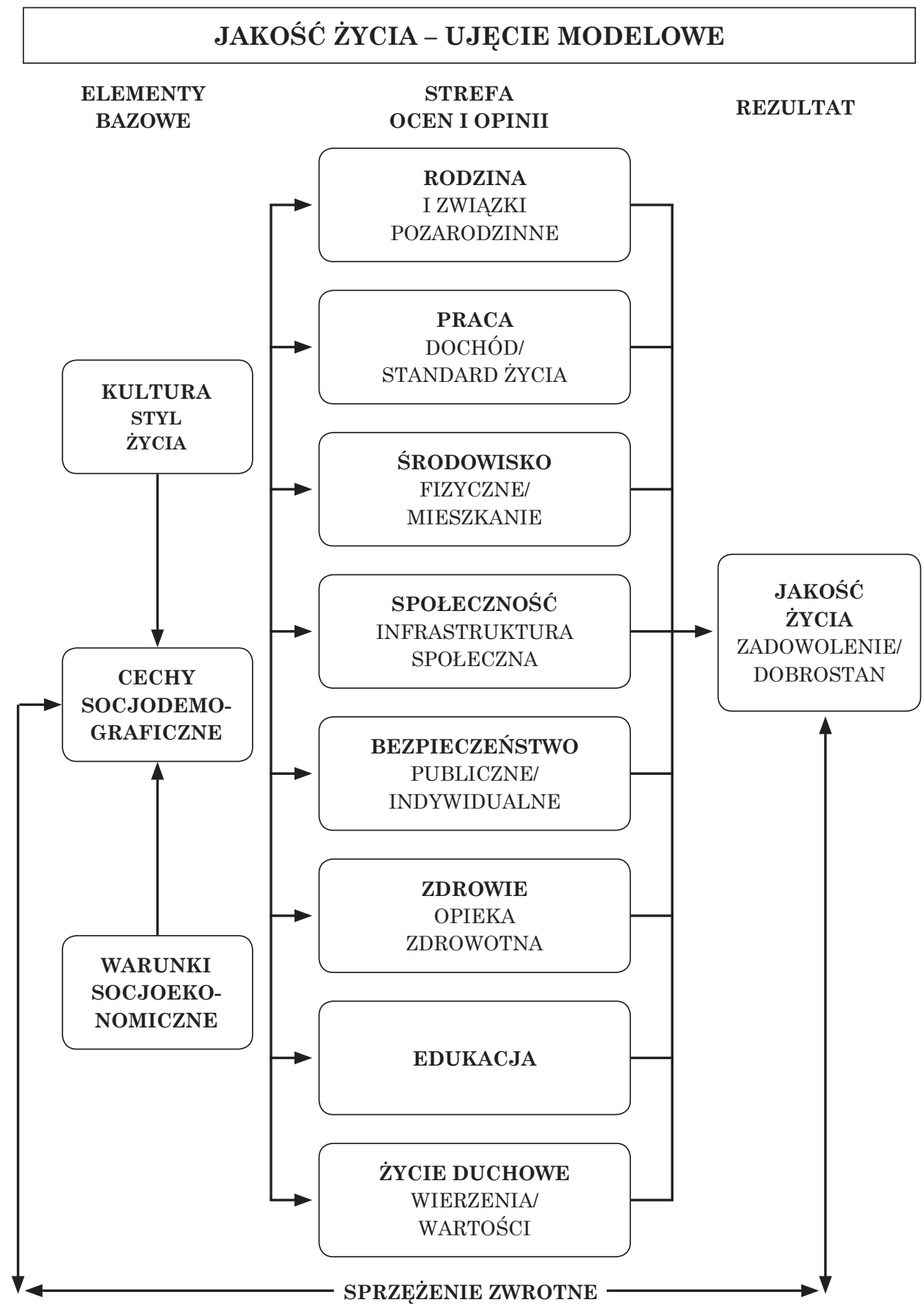

Źródło: zmodyfikowana wersja propozycji University of Oklahoma School of Social Work (Social indicators of the quality of life, http://www.ou.edu/socialwork/research, dostęp: maj 2000). 
Z kolei z polskich danych Diagnozy Społecznej $2013^{25}$ wynika, że:

1. Szczęśliwym wiedzie się lepiej; bardziej szczęście dają np. pieniądze niż pieniądze szczęście. Szczęśliwi mają dużo większe szanse na znalezienie stałego partnera i założenie rodziny.

2. Osoby o nastawieniu materialistycznym gorzej oceniają całe swoje dotychczasowe życie, są mniej szczęśliwe.

3. Województwami o najwyższej ogólnej jakości życia były małopolskie, pomorskie i opolskie, a o najniższej jakości życia - świętokrzyskie, lubuskie i warmińsko-mazurskie. W ostatnich czterech latach najbardziej awansowały województwa małopolskie, podkarpackie i lubelskie, a najbardziej spadły w rankingu jakości życia dolnoślasskie i warmińsko-mazurskie.

4. Polacy widzą coraz słabszy związek między tym, jak im się powodzi (miniony rok był udany), a tym, co robią władze - głównie sobie przypisuja odpowiedzialność za swój status, zwłaszcza jeśli miniony rok zaliczają do udanych.

5. Pod względem ogólnego zaufania zajmujemy jedno z ostatnich miejsc wśród krajów europejskich.

6. Potwierdzona została zależność między kapitałem społecznym a innymi wymiarami jakości życia.

Podstawowym problemem współczesnych konsumentów informacji (władze różnych szczebli, instytucje, media, obywatele itp.) jest nie tyle niewystarczający zasób danych, ile raczej czas dostępu materiałów, które w danym momencie są potrzebne. Równie istotną kwestia jest forma przekazu oraz poziom syntezy faktów i zjawisk ułatwiające odbiór treści w najbardziej istotnym dla odbiorcy informacji momencie. W tej sytuacji przeciążenie informacją stało się jednym z najistotniejszych źródeł stresu i frustracji wśród osób z kręgów decyzyjnych. Pomocnym narzędziem w ogarnięciu i zapanowaniu nad rozproszonymi, surowymi, niezinterpretowanymi materiałami dostępnymi na poziomie gminy lub regionu okazać się może zaproponowany przez autora pakiet analityczny Profil Socjoekonomiczny Społeczności (PSES $)^{26}$, który docelowo może/powinien być obsługiwany przez specjalny program komputerowy ułatwiajacy zbieranie danych, ich analize i prognozowanie. Wymaga to jednak zmiany sprawozdawczości w urzędach i uruchomienia nowych wskaźników analitycznych w statystyce.

25 J. Czapiński, T. Panek (red.), op. cit., s. 1-16.

${ }^{26}$ W wersji z 2011 r. pakiet PSES zawiera w zależności od typu badania 43 wskaźniki w wersji minimum lub 287 wskaźników w wersji maksimum dla 4 profili: d e m o g r a fi c z n e g o - struktura ludności wg płci i kategorii wieku, z d ro w o t n e g o-infrastruktura i dostępność systemu opieki zdrowotnej, stan zdrowia mieszkańców; s ocjoek o no mi c zne go - gospodarka i położenie materialne ludności, edukacja, bezpieczeństwo obywateli, socjokulturowe aspekty funkcjonowania społeczności (w tym funkcjonowanie sektora pozarządowego); s o c j a ln e g o - kadra, zasoby i klienci publicznego sektora pomocy społecznej oraz pozarządowy system wsparcia społecznego; charakterystyka gospodarstw domowych objętych wsparciem. Próby wykorzystania tego narzędzia przy budowie strategii polityki społecznej w Poznaniu, w województwie wielkopolskim i w 9 reprezentatywnych powiatach wielkopolskich nie powiodły się, gminy bowiem, powiaty i regiony nie zbierają danych, na podstawie których można byłoby zbudować wskaźniki pakietu PSES. 


\section{BADANIE JAKOŚCI ŻYCIA W MIEŚCIE ${ }^{27}$}

Jakość życia oznacza wiele różnych rzeczy dla różnych ludzi - w odniesieniu do społeczności (życie w dzielnicy, w konkretnym mieście, gminie, regionie) to czerpanie korzyści z dobrej jakości życia, bez poczucia zagrożenia bezpieczeństwa - w ogóle, w szczególności zaś socjalnego - zamieszkiwanie w dobrej jakości mieszkaniu/domu i z dostępem do edukacji oraz rynku pracy. Tak więc na jakość życia społeczności składają się najważniejsze interpretacje i treści przypisane cechom konkretnej zbiorowości przez jej członków (takich jak bezpieczeństwo zdrowotne i socjalne, dostęp do edukacji, rynku pracy, infrastruktury społecznej oraz do usług i świadczeń społecznych; rekreacja i wypoczynek, transport itp. ${ }^{28}$ - stąd też jakość życia społeczności jest najlepiej rozumiana, gdy się ją ogląda oczyma jej członków.

Jakość życia mieszkańca określonej zbiorowości musi zatem obejmować jakość środowiska życia jednostki, bowiem:

1) daje ono szansę wyjścia naprzeciw podstawowym potrzebom ludzi (żywność, schronienie, bezpieczeństwo, zdrowie, wsparcie społeczne, kontakt społeczny itp.),

2) zakreśla pole działania umożliwiającego wykorzystanie potencjału jednostki, przeciwdziałając marginalizacji, wykluczeniu i bezradności społecznej,

3) stwarza szansę kontroli i wyboru.

Jakość życia w określonym typie zbiorowości terytorialnej (wieś, miasto, dzielnica, osiedle itp.) oznacza czerpanie korzyści i zadowolenia z efektywnego/sprawnego układu instytucjonalnego, funkcjonowanie bez poczucia zagrożenia bezpieczeństwa - w ogóle, socjalnego zaś w szczególności - zamieszkiwanie w dobrej jakości mieszkaniu/domu, otoczeniu społecznym z dostępem do edukacji, rynku pracy, rekreacji i zasobów wsparcia społecznego.

Jakościowy wymiar życia miejskiego oznacza, że jest to przyjemne miejsce do życia, na co składa się witalność ekonomiczna, dostępność i funkcjonowanie transportu, zaopatrzenie, sieć handlowa i usługowa, system bezpieczeństwa, edukacji, opieki zdrowotnej i wsparcia społecznego, możliwości aktywności obywatelskiej (niektóre narzędzia pomiaru mają nawet 200 wskaźników jakości życia w mieście).

Ocena jakości życia w mieście obejmuje poziom osobisty (jednostka ocenia własny poziom zadowolenia w obrębie jej sfer życiowych kontekstowo powiązanych ze społecznością miejska) oraz ewaluację komponentów środowiska miejskiego (infrastruktura i jej dostępność) z punktu widzenia roli w kształtowaniu poczucia zadowolenia wśród mieszkańców ${ }^{29}$.

Cały przedstawiony wcześniej sztafaż definicyjno-metodologiczny stosujemy wówczas, gdy badamy jakość życia w mieście. Wśród niebudzących na ogół

\footnotetext{
${ }^{27}$ R. Rogerson, Quality of Life in Cities, Quality of life Group, Department of Geography, University of Strathclyde; http:/www.2.rudi.net/resrch/quality/qual_int.htm (dostęp: luty 2003).

${ }^{28}$ Propozycja definicyjna World Organization Quality of Life Group (1993).

${ }^{29}$ D. Raphael, B. Steinmetz, R. Renwick, People, Places, and Priorities of Riverdale: Finding from the Community Quality of Life Project, Toronto 1998, Centre for Health Promotion. htttp:// www.utoronto.ca/qol (dostęp: wrzesień 2002).
} 
kontrowersji komponentów jakości życia w mieście (w społeczności/sąsiedztwie/dzielnicy) wymienia się ${ }^{30}$ :

1) piękno natury i zjawiska naturalne;

2) jakość powietrza i poziom hałasu;

3) gęstość zaludnienia oraz gęstość ruchu miejskiego;

4) charakter krajobrazu i jego konserwowanie;

5) cechy architektury oraz jej konserwacja;

6) koszty mieszkania oraz wartość nieruchomości;

7) zatrudnienie i możliwości pracy;

8) ułatwienia dla biznesu, handlu i usług;

9) odpowiednie warunki kształcenia i usług edukacyjnych;

10) możliwości, udogodnienia oraz programy na rzecz rekreacji, kultury i usług socjalnych;

11) usługi i świadczenia publiczne;

12) partycypacja obywateli podejmowaniu decyzji o znaczeniu lokalnym;

13) socjalizacja i stosunki interpersonalne;

14) pomoc wzajemna;

15) zaangażowanie w sprawy sasiedztwa/dzielnicy lub w rozwój i poprawę życia społeczności;

16) cechy społeczne, ekonomiczne, etniczne i rasowe mieszkańców;

17) brak zagrożenia przestępczością.

Wymienione komponenty jakości życia „zatopione” i uwikłane są w szeregu cech i reguł funkcjonowania społeczności miejskiej (dynamiczne, wielopłaszczyznowe ujęcie korelatów jakości życia w mieście odnajdzie czytelnik na diagramie 2).

Z analizy wyników europejskiego badania jakości życia w miastach wynika, $\dot{\mathrm{z}} \mathrm{e}^{31}$ :

1. Mieszkańcom najbardziej zależy na poprawie służby zdrowia, zatrudnienia, edukacji i szkoleń.

2. W większości miast europejskich trudno znaleźć pracę - tylko w 9 miastach większość badanych uważa, że znalezienie pracy jest łatwe. W porównaniu z 2009 r. ryzyko utraty lub niemożność znalezienia pracy znacznie wzrosło.

3. W 50 miastach (na 79) co najmniej połowa respondentów uważa, że trudno znaleźć dobre mieszkanie w przystępnej cenie.

4. Wielu mieszkańców stolic nie jest zadowolonych ze szkół i placówek edukacyjnych.

5. Mieszkańcy dostrzegają też pozytywne strony: w prawie wszystkich miastach (oprócz 5) większość respondentów uważa, że obecność obcokrajowców jest dobra dla miasta i że są oni dobrze zintegrowani.

${ }^{30}$ Zob. D. Russ-Eft, Identifying Components Comprising Neighbourhood Quality of Life, „Social Indicators Research" 6, 1979, s. 349-372.

${ }^{31}$ Quality of Life in Cities, Luxembourg: Publications Office of the European Union, $2013-$ badanie zostało przeprowadzone w 79 miastach wszystkich państw członkowskich UE, a także na Islandii, w Norwegii, Szwajcarii i Turcji (41 000 mieszkańców miast). Badaniami objęto cztery polskie miasta: Białystok, Gdańsk, Kraków i Warszawę (Quality of life in European cities - Poland, Flash Eurobarometr 366, European Commission, January 2014). W rankingu jakości życia w miastach na 53 miejscu w 2014 r. ulokowała się Warszawa i na 54 miejscu Wrocław. 
6. Istnieją duże różnice $\mathrm{w}$ ocenie jakości transportu publicznego, służby zdrowia i własnej sytuacji finansowej.

7. Odnotowano duże zadowolenie z funkcjonowania i wyglądu przestrzeni publicznej, terenów zielonych, czystości i poczucia bezpieczeństwa - wskaźniki ściśle powiązane z ogólnym zadowoleniem z życia w danym mieście.

8. Zadowolona z życia w swoim mieście była większość badanych mieszkańców ( $80 \%$ w 71 miastach).

9. Więcej osób uważa, że władze miast aktywnie działają na rzecz zapobiegania zmianom klimatu - dotyczy to głównie miast stołecznych.

\section{Diagram 2}

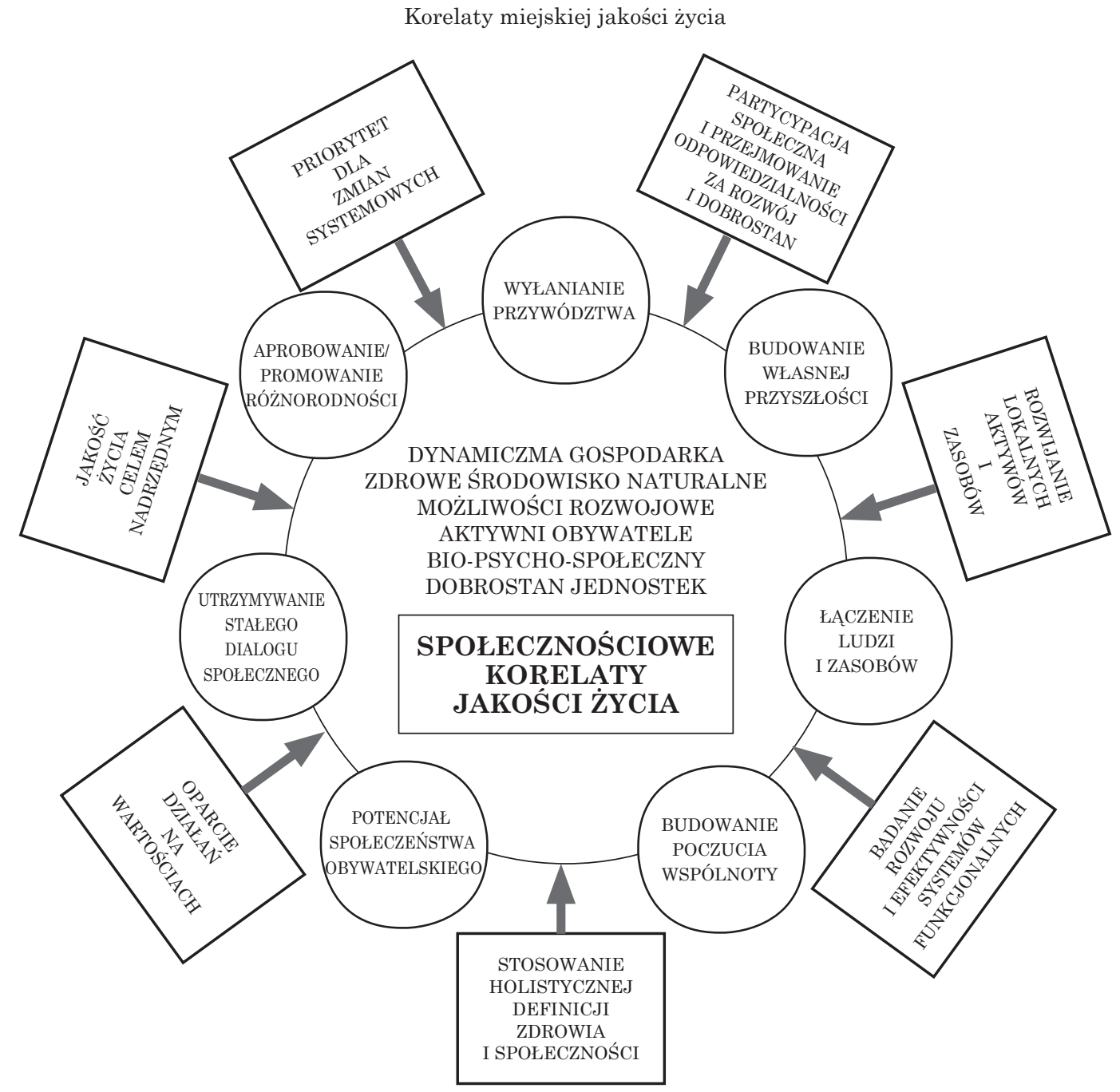

Źródło: opracowanie własne inspirowane propozycjami T. Norris, M. Pittman, The Healthy Communities Movement and the Coalition for Healthier Cities and Communities, „Public Health Reports” 115, 2000, March/April and May/June, s. 6. 
Z ogólnopolskich badań zespołu Czapińskiego dowiadujemy się natomiast, że:

1) najlepiej żyje się mieszkańcom Torunia, Warszawy, Poznania i Krakowa, a najgorzej mieszkańcom Włocławka, Sosnowca i Wałbrzycha;

2) najwięcej bardzo zadowolonych ze swojej miejscowości jest, podobnie jak dwa lata temu, wśród mieszkańców Gdyni, a najmniej wśród mieszkańców Częstochowy, Kielc i Bydgoszczy ${ }^{32}$.

Najdłużej i cyklicznie prowadzone są badania poznańskie, w ramach których jakość życia analizowana były z trojakiej perspektywy:

1) jako komponent kształtujący ogólny poziom jakości życia jednostki (perspektywa znaczacej domeny jakości życia),

2) przez pryzmat zmiennych wpływajacych na postrzeganie stanu zdrowia/sprawności oraz na zdolność psychoemocjonalnego i społecznego funkcjonowania (perspektywa funkcjonalna),

3) wpływu dostępności i jakości opieki zdrowotnej na zadowolenie oraz osiaganie celów osobistych (perspektywa infrastrukturalna) ${ }^{33}$.

Badania poznańskie wyraźnie oddzielaja fakty (infrastruktura miejska) i opinie (oceny funkcjonowania różnych dziedzin życia w mieście - zob. tab. 2), wizualizując rezultaty, nanoszą na mapę miasta dane według intensywności występowania poszczególnych domen jakości życia. Uzyskane wyniki służą ewaluacji i weryfikacji zadań wynikajacych ze strategii polityki społecznej i stanowią dla decydentów przesłankę pogłębienia badań w sferach wykazujacych deficyty i zagrożenia w sferze socjalnej, kulturowej materialnej (do tej pory badano jakość życia osób zagrożonych marginalizacją i wykluczeniem, poczucie bezpieczeństwa i funkcjonowanie komunikacji).

Raporty na temat wielkich miast Polski z 2010 r. ujawniaja kilka istotnych mankamentów - po pierwsze nie są to na ogół badania jakości życia, ale kapitału jakości życia, czyli bazy infrastrukturalnej, warunków instytucjonalnych dla kształtowania jakości życia - to raczej badanie jakości usług ${ }^{34}$. To niepotrzebne mnożenie bytów ponad miarę, marnotrawienie środków i przez stosowanie odmiennej metodologii utrudnia analizę porównawczą ${ }^{35}$. Po drugie, dużemu wysiłkowi badawczemu ${ }^{36}$ nie towarzyszy synteza wyników, zwłaszcza

32 J. Czapiński, op. cit., s. 9.

${ }^{33}$ Od 2001 r. funkcjonuje Centrum Badania Jakości Życia powołane przez Prezydenta m. Poznania i Rektora UAM i kierowane przez dr. hab. Ryszarda Cichockiego z Instytutu Socjologii UAM Jakość życia w Poznaniu (2006, 2008, 2010 i 2013), Wydział Rozwoju Miasta Urzędu Miasta Poznania, http://www.poznan.pl/mim/s8a/raporty-i-analizy,doc,111/jakosc-zycia-w-poznaniu, 50849.html.

${ }^{34}$ Raporty na temat wielkich miast Polski 2010. Poznań, www.pwc.com/pl (dostęp: wrzesień 2012).

${ }^{35}$ Wieloletnie doświadczenia poznańskiego Centrum Badania Jakości Życia nie tylko nie znalazły uznania w oczach Zespołu ds. Usług dla Sektora Publicznego (Oddział Poznań, plac Andersa), ale także wyniki CBJŻ nie znalazły się choćby w omówieniu w raporcie.

${ }^{36}$ Wiele lat temu D. Caplovitz, przestrzegając przed rosnącym zagrożeniem ze strony płaskiego empiryzmu, sformułował tyle żartobliwy, co zmuszający do refleksji w s półc z y n nik ra$\dot{z}$ ącego ulegania empiryzmowi ( $\left.\boldsymbol{D}_{\text {ratio }}\right)$ będący wynikiem podzielenia liczby tabel w raporcie końcowym przez wagę wydruków (w funtach). Jeśli $\mathrm{D}_{\text {ratio }}$ ma wartość większą niż jeden, jest to znak profesjonalizmu, natomiast gdy wartość ta jest mniejsza niż jeden, oznacza to, że badacz otrzymał mniej niż jedną tabelę z użytecznymi wynikami z każdego kilograma wydruków (D. Caplovitz, The Stages of Social Research, New York 1983, s. 257 i n.). 
brak analiz jakości życia z uwzględnieniem zmiennych informujących o statusie społecznym, socjalnym i zdrowotnym badanych - inaczej mówiąc, nie dysponujemy profilami socjodemograficznymi, zdrowotnymi różnych aspektów jakości życia.

\section{Tabela 2}

Domeny i wskaźnik jakości życia stosowane w badaniach poznańskich

\begin{tabular}{|c|c|}
\hline $\begin{array}{l}\text { Zdrowie i opieka zdrowotna } \\
\text { 1. Samoocena stanu zdrowia } \\
\text { 2. Samoocena zdrowia w codziennym funk- } \\
\text { cjonowaniu } \\
\text { 3. Ocena samopoczucie w ostatnich } 12 \text { mie- } \\
\text { siącach } \\
\text { 4. Ocena dostępności usług medycznych } \\
\text { 5. Ocena jakości świadczeń medycznych do- } \\
\text { konana przez mieszkańców }\end{array}$ & $\begin{array}{l}\text { Bezpieczeństwo socjalne } \\
\text { 1. Ocena własnych warunków materialnych } \\
\text { oraz możliwości finansowych } \\
\text { 2. Ocena możliwości uzyskania wsparcia } \\
\text { finansowego } \\
\text { 3. Ocena aktywności władz miejskich w dzie- } \\
\text { dzinie ochrony bezpieczeństwa socjalnego. } \\
\text { 4. Ocena zasobów i dostępność pomocy spo- } \\
\text { łecznej }\end{array}$ \\
\hline $\begin{array}{l}\text { Bezpieczeństwo fizyczne } \\
\text { 1. Ocena zagrożenia ze strony sprawców } \\
\text { przestępstw } \\
\text { 2. Ocena bezpieczeństwa w dzień i w nocy } \\
\text { 3. Ocena instytucji organów ścigania i wy- } \\
\text { miaru sprawiedliwości } \\
\text { 4. Ocena aktywności władz miejskich w sfe- } \\
\text { rze zapewnienia bezpieczeństwa fizycznego } \\
\text { 5. Ocena poziomu bezpieczeństwa na drogach } \\
\text { 6. Ocena działalności służb ratunkowych }\end{array}$ & $\begin{array}{l}\text { Kultura i aktywność w czasie wolnym } \\
\text { 1. Ocena ilości czasu wolnego } \\
\text { 2. Ocena możliwości spędzania czasu wolne- } \\
\text { go poza domem } \\
\text { 3. Ocena funkcjonowania instytucji kultu- } \\
\text { ralnych } \\
\text { 4. Ocena możliwości uczestnictwa w życiu } \\
\text { kulturalnym miasta } \\
\text { 5. Ocena stanu miejsc rekreacji i wypoczynku } \\
\text { w mieście } \\
\text { 6. Ocena atrakcyjności turystycznej miasta }\end{array}$ \\
\hline $\begin{array}{l}\text { Stan środowiska przyrodniczego } \\
\text { 1. Ocena czystości powietrza w mieście } \\
\text { 2. Ocena poziomu hałasu w mieście } \\
\text { 3. Ocena czystości miejsc publicznych } \\
\text { 4. Ocena jakości wody pitnej w mieście } \\
\text { 5. Ocena zanieczyszczenia środowiska } \\
\text { 6. Ocena gospodarki odpadami w mieście } \\
\text { 7. Gotowość uczestnictwa w ochronie środo- } \\
\text { wiska }\end{array}$ & $\begin{array}{l}\quad \text { Praca i warunki materialne } \\
\text { 1. Ocena warunków i możliwości pracy } \\
\text { 2. Ocena miejskiego rynku pracy } \\
\text { 3. Ocena możliwości działalności gospodar- } \\
\text { czej } \\
\text { 4. Ocena relacji społecznych w miejscu pracy } \\
\text { 5. Ocena poziomu bezrobocia } \\
\text { 6. Ogólna ocena i prognozowanie sytuacji } \\
\text { życiowej }\end{array}$ \\
\hline $\begin{array}{l}\text { Edukacja } \\
\text { 1. Ocena oferty oświatowej miasta } \\
\text { 2. Ocena warunków pracy szkoły i nauczy- } \\
\text { cieli } \\
\text { 3. Ocena wymagań stawianych uczniom } \\
\text { 4. Ocena bezpieczeństwa w szkole } \\
\text { 5. Ocena ogólna funkcjonowania szkół } \\
\text { i przedszkoli }\end{array}$ & $\begin{array}{l}\text { Mieszkanie i sąsiedztwo } \\
\text { 1. Ocena możliwości zaspokojenia potrzeb } \\
\text { mieszkaniowych } \\
\text { 2. Ocena kosztów użytkowania mieszkania } \\
\text { 3. Poziom zadowolenia z własnych warunków } \\
\text { mieszkaniowych } \\
\text { 4. Poziom zadowolenia z usytuowania miesz- } \\
\text { kania/domu } \\
\text { 5. Ocena otoczenia mieszkania/domu. } \\
\text { 6. Zadowolenie z sasiedztwa } \\
\text { 7. Poczucie bezpieczeństwa w miejscu za- } \\
\text { mieszkania }\end{array}$ \\
\hline
\end{tabular}


cd. tab. 2

\begin{tabular}{|l|l|}
\hline \multicolumn{1}{|c|}{$\begin{array}{l}\text { Przestrzeń i infrastruktura miejska } \\
\text { Ocena funkcjonowania komunikacji miej- } \\
\text { skiej }\end{array}$} & \multicolumn{1}{c|}{$\begin{array}{c}\text { Funkcjonowanie władz } \\
\text { i instytucji miejskich }\end{array}$} \\
$\begin{array}{l}\text { 2. Ocena warunków funkcjonowania komuni- } \\
\text { kacji indywidualnej }\end{array}$ & $\begin{array}{l}\text { 1. Ocena źródeł, jakości i zawartości informa- } \\
\text { cji miejskiej }\end{array}$ \\
$\begin{array}{l}\text { 3. Ocena warunków funkcjonowania komuni- } \\
\text { kacji rowerowej }\end{array}$ & $\begin{array}{l}\text { 2. Ocena poczucia związku z miastem } \\
\text { 3. Ocena funkcjonowania instytucji miejskich }\end{array}$ \\
$\begin{array}{l}\text { 4. Ocena ogólna warunków życia w mieście. } \\
\text { użytku publicznego }\end{array}$ & $\begin{array}{l}\text { 5. Ocena udziału mieszkańców w życiu pub- } \\
\text { licznym }\end{array}$ \\
$\begin{array}{l}\text { Dostępność przestrzeni publicznej dla osób } \\
\text { z niepełnosprawnością }\end{array}$ & $\begin{array}{l}\text { 6. Ocena działalności rady miasta } \\
\text { 7. Ocena Prezydenta Miasta }\end{array}$ \\
\hline
\end{tabular}

Źródło: Wydział Rozwoju Miasta Urzędu Miasta Poznania, http://www.poznan.pl/mim/s8a/raporty-i-analizy,doc,111/jakosc-zycia-w-poznaniu,50849.html (dostęp: styczeń 2014).

Konkludując: dane na temat warunków życia to tylko ilustracja zasobów infrastruktury (zmienna statyczna) - najistotniejsza jest korelacja zmiennych przypisanych respondentom $\mathrm{z}$ ich subiektywną oceną jakości życia (zmienna dynamiczna). Istotne poznawczo, a zwłaszcza przydatne w praktyce życia społecznego sa informacje o tym:

1) jakie domeny jakości życia mają istotne znaczenie w kształtowaniu ogólnego poziomu zaspokojenia potrzeb oraz oceny dostępności i funkcjonowania infrastruktury miejskiej (profil jakości życia);

2) kim są mieszkańcy z poszczególnych profili według cech społeczno-demograficznych i zmiennych określających ich warunki życia (płeć, wiek, wykształcenie, status materialny itp.).

Badania jakości życia w mieście winny być prowadzone na użytek polityki lokalnej oraz na potrzeby analizy porównawczej dla miast polskich i europejskich. Dlatego powinno się dążyć do zsynchronizowania koncepcji i metod badawczych poszczególnych zespołów oraz uzgodnienia wskaźników jakości życia w mieście.

\section{PODSUMOWANIE}

Poprawa jakości naszego życia staje się współcześnie coraz częściej ostatecznym celem polityki publicznej realizowanej na rzecz społeczności ${ }^{37}$ - zbiorowości, w ramach której ludzie mają poczucie bycia częścią c z e g o ś, wykonuja „pełen obrót” w formach indywidualnej aktywności życiowej (nauka, praca,

${ }^{37}$ To oficjalne stanowisko Setretarza Generalnego OECD, Angeli Gurría, przedstawione podczas: Introductory remarks at OECD Forum 2011, first Session on Measuring Progress on 24 May 2011 in Paris, France (Downloaded from www.beyond-gdp.eu/key_quotes.html; dostęp: wrzesień 2003). 
rozrywka i wypoczynek, kontakty społeczne itp.), mają poczucie sensu bycia włączonym razem z innymi we wspólny układ możliwości i wpływów ${ }^{38}$.

Szansą poprawy jakości życia współczesnych społeczeństw jest ogniskowanie wysiłków państwa i jego statutowych i wyspecjalizowanych instytucji na wzmacnianiu potencjału zasobów ludzkich ${ }^{39}$. Dlatego każda społeczność dąży do zbudowania w miarę spójnego i funkcjonalnego systemu zapewniającego godne warunki pracy i życia oraz realizację zadań istotnych dla trwania i rozwoju wspólnoty, służących zwiększaniu zaradności, solidarności zbiorowej i uczestnictwu ludzi w życiu zbiorowym, zapewniając instytucjonalną ochronę bezpieczeństwa fizycznego i socjalnego swych członków. Oznacza to, że współczesna polityka społeczna wykracza daleko poza prostą redystrybucję dochodów i dóbr, domeny polityki ekonomicznej (gospodarczej) zaś obsługiwać muszą cele społeczne (rozwój zrównoważony).

Trwa szeroka debata na temat praktycznego znaczenia badań jakości życia, także w mieście, której towarzyszy rosnąca świadomość, że nie można jej ewaluować w rutynowych, standardowych terminach dostarczania świadczeń i usług lub wprowadzania ułatwień w funkcjonowaniu mieszkańców w ich środowisku miejskim.

Badania jakości życia poszerzają sieć sygnałową zmian pojawiających się w infrastrukturze społecznej ${ }^{40}$ zróżnicowanych kategorialnie zbiorowości oraz ocen funkcjonowania społeczności i jej instytucji, dokonywanych przez obywateli. Pozwalają one władzom publicznym identyfikować i oceniać czynniki mające największy wpływ na bieżąca, jednostkową ocenę różnych domen życia miejskiego oraz tych jego aspektów, które byłyby podatne na zmianę/poprawę. Pomiar jakości życia mieszkańców to bardzo przydatne narzędzie ewaluacji miejskiej strategii rozwoju (w tym strategii polityki społecznej) i szansa wczesnego ujawniania niedoborów oraz deficytowych i/lub dysfunkcjonalnych obszarów życia miejskiego, wymagających pogłębionych analiz. To baza korekty tego, co przeszkadza ludziom osiagnać oczekiwaną jakość życia, określenie przyczyn niedomogów i podjęcie działań korygujących. To także dostarczanie władzom samorządowym informacji o potrzebach, preferencjach i wyborach dokonywanych przez mieszkańców społeczności (sprzężenie zwrotne),

Tak więc jakość życia związana $\mathrm{z}$ funkcjonowaniem jednostek w środowisku miejskim obejmuje nie tylko charakterystyki fizyczne miejsc, w których ludzie żyja, pracują i wypoczywaja, ale również takie społeczne atrybuty tego środowiska, jak poczucie sensu i znaczenia społeczności, wartość sassiedztwa, sens towarzyskości.

Miasta, dążąc do utrzymania/odzyskania waloru atrakcyjnego miejsca do życia i zatrzymania exodusu mieszkańców dużych miast na wieś,

${ }^{38}$ To zatem miejsce, gdzie JA pracuję i gdzie JA realizuję MOJE potrzeby i zainteresowania.

39 Zob. F. Harbison, Human Resources as the Wealth of Nation, Oxford 1973.

${ }^{40}$ Infrastruktura społeczna to celowo rozmieszczona sieć urządzeń, której elementami są odpowiednio rozwiązane instytucje i obiekty stwarzające warunki elastycznego realizowania założonych funkcji w zaspokajaniu potrzeb społecznych przez stosowanie nowoczesnych rozwiąań naukowych, technologicznych i materiałowych oraz przez profesjonalnie przygotowaną kadrę działającą w określonym systemie organizacyjno-prawnym. 
muszą zwrócić się ku tym właśnie wymienionym wyżej atrybutom ${ }^{41}$. Przywrócenie jakości miejskiemu życiu oznaczać musi partnerstwo władz lokalnych z poszczególnymi podmiotami społeczności miejskiej. Dobre planowanie w pojedynkę nie daje gwarancji wysokiej jakości życia miejskiego - indywidualizm i wolny rynek muszą być wsparte partycypacją i uspołecznieniem decyzji. Takie pluralistyczne i partycypacyjne podejście w relacjach władz publicznych z mieszkańcami to potwierdzona w wielu krajach szansa autentycznej poprawy jakości życia dla wszystkich.

prof. dr hab. Zbigniew Woźniak

Uniwersytet im. Adama Mickiewicza w Poznaniu

zbig@amu.edu.pl

\section{CONTINUOUS RESEARCH ON QUALITY OF LIFE \\ AS A USEFUL TOOL FOR CITY DEVELOPMENT STRATEGY}

Sum mary

Macroeconomic processes with long-term implementation perspectives only take into partial consideration the obstacles, short-term consequences and weaknesses which they can inflict on the functioning of a particular individual, family or community. It is becoming more and more important to enlarge the set of tools measuring social well-being, apart from the standard measurement of the Gross Domestic Product (GDP). What becomes far more significant is measuring the welfare of citizens and their life satisfaction because these factors reflect the value of the city as an 'attractive place to live.'

Research into quality of life in the cities brings local authorities knowledge about the needs, preferences and choices made by the members of the city community and their opinion of city infrastructure and its accessibility. For those who are responsible for further city development, these data should become the background for all development strategies and they should spur new economic, social and cultural growth.

\footnotetext{
${ }^{41}$ Władze próbują odnowić dumę i jakość miejskiego życia oraz kultury miejskiej. W Wielkiej Brytanii powstała np. Millenium Commission fundująca nagrodę za „najlepsze małe gesty, które przyczyniają się do jakości życia środowiska publicznego na poziomie społeczności”. Jesteśmy także świadkami gentrification, głównego procesu ożywiania miast. Ta odnawialność przestrzeni miejskiej to efekt aktywności ludzi młodych oraz elit profesjonalnych, dla których życie w mieście postrzegane jest jako szansa powiększenia potencjału jakości życia (R. Rogerson, Quality of Life in Cities, Quality of life Group, Department of Geography, University of Strathclyde; http:// www.2.rudi.net/resrch/quality/qual_int.htm; dostęp: luty 2003).
} 
